\title{
Aspek Hukum Merger dan Akuisisi Pada Lembaga Keuangan Koperasi
}

\author{
I Gusti Agung Didit Eka Permadi ${ }^{1}$ \\ Fakultas Ekonomi dan Bisnis Universitas Mahasaraswati Mataram, \\ JL. Amir Hamzah, No. 11, Sukun, Mataram 83127, \\ Telp. (0370) 643577 \\ Email: igadiditekapermadi@mail.com \\ Agung Wisudawan ${ }^{2}$ \\ Fakultas Hukum Universitas Mataram, \\ Jln. Majapahit No. 62 Mataram 83125, \\ Telp. (0370), 633035, Fax. 626954 \\ Email: igwisudawan@mail.com
}

\begin{abstract}
Mergers and Acquisitions is a legal phenomenon that occurs in companies incorporated as legal entities including financial institutions. Mergers and Acquisitions aim to strengthen institutional structures and strengthen cooperative capital in the hope of improving member welfare. The legal aspects of Mergers and Acquisitions on cooperatives emphasize the legality aspect, the reasons for Mergers and Acquisitions, the processes and their legal consequences. It's just that the Acquisition in the future must be calculated and regulated in legislation because not many cooperatives are doing it Acquisition is needed as one business strategy to develop cooperatives to exist in the middle of society.
\end{abstract}

Kata Kunci : Mergers, Acquisitions, Cooperative.

\section{A. PENDAHULUAN}

Koperasi merupakan soko guru perekonomian bangsa Indonesia, yang keberadaannya sangat dibutuhkan oleh masyarakat. Tujuan didirikannya koperasi adalah untuk kesejahteraan anggota pada khususnya dan meningkatkan kesejahteraan masyarakat pada umumnya. Eksistensi koperasi hari ini telah diakui manfaatnya terutama oleh masyarakat baik masyarakat golongan ekonomi menengah maupun masyarakat ekonomi rendah. Apalagi pada

1 Dosen Fakultas Ekonomi dan Bisnis Universitas Mahasaraswati Mataram.

2 Dosen Fakultas Hukum Universitas Mataram. 
saat ini Indonesia sedang menghadapi era perdagangan bebas di kawasan Asia maka lembaga keuangan koperasi dituntut lebih profesional dalam mengelola usahanya agar bermanfaat bagi masyarakat.

Menurut Agung Wisudawan menyatakan bahwa "Jumlah koperasi yang ada pada saat ini di Indonesia kian hari kian bertambah seiring dengan besarnya kebutuhan serta keinginan masyarakat untuk membuka usaha baru ataupun untuk sekedar melestarikan pola hidup yang serba konsumtif. Kelebihan yang dimiliki lembaga keuangan koperasi ini dibandingkan dengan yang lain adalah kemudahan untuk menjadi anggota yaitu dengan membayar simpanan pokok dan simpanan wajib yang telah ditentukan oleh koperasi itu sendiri, sehingga berimplikasi kepada kemudahan untuk memperoleh kredit maupun untuk menyimpan dana anggota dalam bentuk simpanan berjangka". ${ }^{1}$ Pola hidup masyarakat Indonesia yang serba konsumtif sehingga menimbulkan adanya pinjaman atau kredit dan keinginan masyarakat untuk menyimpan dananya merupakan hal yang mendorong lahirnya lembaga keuangan koperasi di Indonesia.

Berikut ini beberapa sarjana memberikan pengertian tentang Koperasi yaitu :

1. Ropke menyatakan bahwa koperasi adalah organisasi bisnis yang para pemilik atau anggotanya adalah juga pelanggan utama perusahaan tersebut (criteria identitas). Kriteria identitas suatu koperasi akan merupakan dalil atau prinsip identitas yang membedakan unit usaha koperasi dari unit usaha yang lainnya. ${ }^{2}$

2. Selain itu Koperasi adalah organisasi yang otonom, yang berada dalam lingkungan sosial ekonomi yang

\footnotetext{
1 I Gusti Agung Wisudawan, Jurnal Ilmiah Ganec Swara Vol 8 No 2 Edisi September Tahun 2014

2 Hendar Kusnadi, Ekonomi Koperasi, Lembaga Penerbit Fakultas Ekonomi UI,2005. Hal 21
}

memungkinkan setiap individu dan sekelompok orang merumuskan tujuan tujuannya secara otonom dan mewujudkan tujuan-tujuan itu melalui aktivitas ekonomi yang dilaksanakan secara bersama-sama .

3. Menurut ILO Recommendation No. 127, 1966 pada paragraph 12 (a) mengatakan tentang definisi koperasi yaitu : " Koperasi adalah suatu perkumpulan orang-orang yang secara sukarela berhimpun bersama untuk mencapai suatu tujuan bersama melalui pembentukan suatu organisasi yang diawasi secara demokratis memberi sumbangan yang wajar di dalam modal yang diperlukan dan menerima bagian yang wajar dalam penaggungan resiko dan manfaat dari perusahaan di dalam mana para anggota berperan secara aktif".

Sedangkan menurut Pasal 1 Undangundang No 25 Tahun 1992 Tentang Perkoperasian menyatakan bahwa “ Koperasi adalah Badan Usaha yang beranggotakan orang seorang atau badan hukum koperasi dengan berlandaskan kegiatannya berdasarkan prinsip koperasi sekaligus sebagai gerakan ekonomi rakyat yang berdasar atas asas kekeluargaan. Berdasarkan pengertian Pasal 1 Undangundang No 25 Tahun 1992 Tentang Perkoperasian di atas bahwa Koperasi merupakan badan usaha sekaligus merupakan badan hukum yang didirikan berdasarkan gerakan ekonomi kerakyatan dan berdasarkan asas kekeluargaan. Jadi dalam pengeloaan koperasi asas kekeluargaanlah yang menjadi ciri pokoknya sehingga jika terjadi hal-hal apakah itu yang berkaitan dengan strategi operasional, kebijakan merger atau penggabungan atau peleburan koperasi maupun perbuatan hukum lain selama tidak menyentuh ranah pidana dapat diselesaikan

\footnotetext{
3 Soedarsono Hadisapoetro, Pokok-Pokok Pikiran Pengembangan Koperasi Indonesia, CV. Sapta Caraka, 1986,104
} 
dengan mengunakan asas kekeluargaan dengan semangat gotong royong yang salah satu perwujudannya adalah musyawarah dalam Rapat Anggota.

Fenomena hukum yang menarik untuk dibahas pada tulisan ini yang berkaitan dengan lembaga keuangan koperasi adalah Merger dan Akuisisi. Merger memang identik dengan penggabungan sedangkan Akuisisi merupakan pengambil alihan aset untuk dikelola. Dalam pelaksanaan baik itu Merger maupun Akuisisi perlu ditelaah secara seksama terutama yang berkaitan dengan aspek hukumnya dan akibat hukum setelah adanya ke dua fenomena tersebut. Sebab Merger atau Penggabungan Koperasi saja yang diatur dalam bentuk Peraturan Menteri Koperasi dan UMKM sedangkan fenomena Akuisisi sendiri belum diatur sedangkan kalau dicermati pada perkembangannya tidak hanya merger saja yang dapat dilakukan tetapi Akuisisi juga dapat dilakukan pada lembaga keuangan koperasi dan harus pula diatur di dalam Peraturan Menteri Koperasi dan UMKM. Berdasarkan hal tersebut di atas maka terdapat beberapa hal yang perlu dinalisis di dalam penulisan ini khususnya yang terkait dengan Bagaimana aspek hukum Merger dan Akuisisi dalam Lembaga Keuangan Koperasi.

\section{B. METODE PENELITIAN}

Jenis penelitian yang dilakukan dalam penelitian ini adalah penelitian yuridis normatif yaitu penelitian yang mengkaji /meneliti baik bahan hukum primer yang terdiri dari undang-undang, peraturan-peraturan yang berkaitan dengan

\footnotetext{
4 Hirsanuddin, Muhaimin dan Ari Rahmad Hakim dan Yudhi Setiawan, Kewenangan Otoritas Jasa Keuangan Dalam Pengaturan dan Pengawasan di Sektor Perbankan, Jurnal Hukum Jatiswara Volume 31, No1Maret 2016 Hal 11

5 Johnny Ibrahim, Teori dan Metodelogi Penelitian Hukum Normatif, Bayumedia Publishing, Surabaya, 2005, Hal 255
}

masalah yang diteliti juga mengaji bahan hukum skunder yang terdiri dari literaturliteratur dan pendapat para sarjana yang terkait dengan masalah yang diteliti. ${ }^{4}$

Pendekatan yang digunakan dalam penulisan ini yaitu pendekatan peraturan perundang-undangan (Statute Approach) yaitu pendekatan yang melakukan pengkajian terhadap peraturan perundangundangan yang menjadi tema sentral dalam penelitian ini. ${ }^{5}$ Pendekatan Konsep ( Conceptual Approach) yaitu konsep dalam ilmu hukum dapat diartikan titik tolak atau pendekatan bagi analisis penelitian hukum, karena akan banyak muncul konsep bagi suatu fakta hukum. ${ }^{6}$ Selanjutnya dianalisis secara deskriptif kualitatif.

\section{PEMBAHASAN}

\section{Aspek Hukum Merger dan Akuisisi dalam}

\section{Lembaga Keuangan Koperasi}

Menurut ketentuan Pasal 1 Undangundang No 25 Tahun 1992 Tentang Perkoperasian menyatakan bahwa Koperasi adalah " Badan usaha yang beranggotakan orang seorang atau badan hukum koperasi dengan berlandaskan kegiatannya berdasarkan prinsip koperasi sekaligus sebagai gerakan ekonomi rakyat yang berdasar atas asas kekeluargaan". Adapun tujuan koperasi yaitu “ memajukan kesejahteraan anggota pada khususnya dana masyarakat pada umumnya serta ikut membangun tatanan perekomian nasional dalam rangka mewujudkan masyarakat yang maju, adil dan makmur berdasarkan Pancasila dan UUD 1945". Prinsip-prinsip umum koperasi Indonesia diatur di dalam

\footnotetext{
6 MuktiFajar \& Yulianto Achmad, Dualisme Penelitian Hukum Normatif dan Empiris, Pustaka Pelajar, Yogyakarta, 2009, Hal 187
} 
Pasal 15 ayat (1) Undang-undang No 25 Tahun 1992 Tentang Perkoperasian yaitu :

a) Keanggotaan bersifat sukarela dan terbuka

b) Pengelolaan dilakukan secara demokratis

c) Pembagian sisa hasil usaha dilakukan secara adil sebanding dengan besarnya jasa usaha masing-masing anggota.

d) Pembagian balas jasa yang terbatas pada modal

e) Kemandirian.

Adapun fungsi koperasi adalah sebagai berikut :

1. alat perjuangan ekonomi untuk mempertinggi kesejahteraan rakyat.

2. alat pendemokrasian nasional

3. alat pembinaan insane masyarakat untuk memperkokoh kedudukan ekonomi bangsa Indonesia serta bersatu dalam mengatur tatalaksana perekonomian rakyat. ${ }^{7}$

Menurut Pasal 15 Undang-undang No 25 Tahun 1992 Tentang Perkoperasian mengatur tentang jenis koperasi yaitu : "Koperasi dapat berbentuk koperasi primer dan koperasi sekunder. Adapun yang dimaksud dengan Koperasi Primer yaitu koperasi yang didirikan oleh dan beranggotakan orang seorang, koperasi ini dibentuk sekurang-kurangnya 20 (dua puluh) orang, sedangkan Koperasi Sekunder yaitu koperasi yang didirikan oleh dan beranggotakan koperasi. Koperasi sekunder dibentuk sekurang-kurangnya 3 (tiga) koperasi. Terdapat empat tingkatan organisasi koperasi yaitu : ${ }^{8}$

1. Koperasi Primer, dibentuk sekurangkurangnya 20 (dua puluh) orang yang telah memenuhi syarat-syarat

7 Sudarsono \& Edilius,Koperasi Dalam Teori dan Praktek,PT. Rineka Cipta, 2005. Hal 80

${ }^{8}$ Muhammad Firdaus \& Agus Edhi Susanto,Perkoperasian Sejarah,Teori dan Praktek,2004, Hal 62. keanggotaan sebagaimana ditentukan dalam undang-undang

2. Pusat Koperasi, terdiri dari sekurangkurangnya 5 (lima) koperasi primer yang berbadan hokum.

3. Gabungan Koperasi, terdiri sekurangkurangnya 3 (tiga) pusat koperasi yang berbadan hokum.

4. Induk Koperasi, terdiri sekurangkurangnya 3 (tiga) gabungan koperasi yang berbadan hukum.

Dalam menjalankan kegiatannya koperasi berpegang teguh kepada prinsipprinsip koperasi sebagaimana yang terdapat di dalam Pasal 5 ayat (1) Undang-undang No 25 tahun 1992 yang menyatakan bahwa

(1) Koperasi menjalankan prinsip koperasi sebagai berikut :

a. Keanggotaan bersifat sukarela dan terbuka

b. Pengelolaan dilakukan secara demokratis

c. Pembagian sisa hasil usaha dilakukan adil dan sebanding dengan besarnya jasa usaha masing-masing anggota.

d. Pemberian balas jasa terbatas terhadap modal

e. Kemandirian

Sedangkan dalam mengembangkan koperasi, maka koperasi melaksanakan pula prinsip koperasi sebagaimana yang dimaksud di dalam Pasal 5 ayat (2) Undangundang No 25 tahun 1992 yang menyatakan sebagai berikut :

a. Pendidikan perkoperasian

b. Kerjasama antar anggota

Menurut Pasal 16 Undang-Undang

No 25 Tahun 1992 Tentang Perkoperasian menyatakan bahwa :" Jenis koperasi didasarkan pada kesamaan kegiatan dan kepentingan ekonomi anggotanya". Selanjutnya adapun jenis koperasi pada umumnya yaitu $:{ }^{9}$

\footnotetext{
9 Luh Putu Khristina Dewi, Tanggung Jawab Lembaga Keuangan Koperasi Terhadap Anggota Atas Perbuatan Melawan Hukum Yang Dilakukan Pengurus Menurut Undang-Undang Nomor 25 Tahun 1992 Tentang Perkoperasian, Skripsi FH
}

4 I Gusti Agung Didit Eka Permadi dan I gusti Agung Wisudawan | [Aspek Hukum Merger...] 
1. Koperasi Konsumsi yaitu koperasi yang anggotanya terdiri dari tiap-tiap orang yang mempunyai kepentingan langsung dengan konsumsi, fungsi koperasi konsumsi adalah sebagai penyalur tanggal barang-barang kebutuhan rakyat sehari-hari ke konsumen, dan harga barang sampai ke tangan pemakai menjadi murah.

2. Koperasi Produksi yaitu koperasi yang anggotanya menghasilkan barang atau jasa.

3. Koperasi simpan pinjam yaitu koperasi yang berkaitan langsung dengan pekreditan tentunya denga jaminan baik itu jaminan fiducia maupun jaminan berdasarkan hak tanggungan. Adapun tujuan dari koperasi simpan pinjam yaitu : membantu keperluan kredit para anggotanya yang sangat membutuhkan dengan syarat ringan, mendidik para anggotanya supaya giat menyimpan secara teratur sehingga membentuk modal sendiri dan mendidik anggotanya untuk hidup berhemat dengan menyisihkan sebagaian pendapatan.

4. Koperasi Jasa yaitu koperasi yang berusaha dibidang tertentu bagi anggotanya dan masyarakat pada umumnya.

5. Koperasi Serba Usaha/Koperasi Unit Desa (KUD) yaitu koperasi yang bertujuan meningkatkan produksi dan kesejahteraan rakyat di daerah pedesaan.

Pengelolaan koperasi tidak lepas dari pernanan sentral dari perangkat koperasi sebagaimana yang terpadat di dalam Pasal 21 Undang-Undang No 25 Tahun 1992 Tentang Perkoperasian yang menyatakan bahwa :

Perangkat Organisasi Koperasi terdiri dari :
1. Rapat Anggota

2. Pengurus

3. Pengawas.

Lebih lanjut di dalam koperasi terdapat pemegang kekuasaan tertinggi sama seperti halnya RUPS (Rapat Umum Pemegang Saham) pada Perseroan Terbatas tetapi hanya lain istilahnya saja, pada koperasi pemegang kekuasaan tertinggi adalah RAT (Rapat Anggota Tahunan) hal ini juga diatur secara normatif di dalam Pasal 22 Undang-Undang No 25 Tahun 1992. Dalam Rapat Anggota merupakan rapat pertanggunggjawaban pengurus terhadap pengeolaan koperasi selama satu tahun baik di bidang keuangan, manajemen, pengangkatan dan pemberhentian pengurus dan pengawas, menetapkan rencana kebijakan koperasi jangka panjang, pendek dan menengah serta evaluasi lainnya yang dianggap perlu untik kemajuan koperasi. Pengurus adalah ujung tombak terpenting dalam pengelolaan koperasi, pengurus haruslah professional, jujur, memiliki integritas dan moralitas demi kelancaran usaha koperasi itu sendiri, tentu saja tidak hanya melindungi secara hukum bagi anggota saja tetapi juga kepada lembaga koperasi itu sendiri. Perlu diingat bahwa antara perangkat organisasi koperasi yang satu dengan yang lain harus saling mendukung dan memiliki hubungan yang sinergis, kondusif serta komperhensif antara satu dengan yang lain guna mewujudkan pengelolaan koperasi yang profesional.

Merger dan Akuisisi merupakan fenomena hukum dan sebagai salah satu strategi dalam dunia perusahaan dan dapat terjadi pada lembaga keuangan koperasi, sebab koperasi merupakan badan usaha yang badan hukum ${ }^{10}$ yang menjadi salah satu subjek hukum. berikut ini Penulis akan menguraikan satu persatu tentang apa itu

10 H. Zainal Asikin \& Wira Pria Suhartana, Pengantar Hukum Perusahaan, Prenadamedia Group, Jakarta, 2016., Hal 7 
Merger dan Akuisisi, yang pertama Merger merupakan penggabungan perusahaan. Berikut ini beberapa pengertian Merger menurut para sarjana hukum bisnis yaitu : ${ }^{11}$

a. Barceliaus Ruru mengartikan Merger sebagai penggabungan usaha dari dua atau lebih peruusahaan yang bergabung ke dalam satu perusahaan yang telah ada sebelumnya.

b. Kartini Muliadi mengartikan bahwa Merger sebagai transaksi dua atau lebih perseroan menggabungkan usaha mereka berdasarkan peraturan perundang-undangan yang ada sehingga hanya satu perseroan saja yang tinggal.

\section{Sedangkan menurut M.E Hitt} menyatakan bahwa Merger adalah suatu strategi bisnis yang diterapkan dengan menggabungkan antara dua atau lebih peruahaan yang setuju menyatukan kegiatan operasionalnya dengan basis yang relative seimbang karena mereka memiliki sumber daya dan kapabilitas yang secara bersama-sama dapat menciptakan keuanggulan kompetitif yang lebih kuat. ${ }^{12}$ Senada dengan hal tersebut menurut Ketentuan Pasal 1 angka 9 Undang-undang No 40 Tahun 2007 Tentang Perseroan Terbatas menyatakan bahwa Merger adalah perbuatan hukum yang dilaukan oleh 1 (satu) perseroan atau lebih untuk menggabungkan diri dengan perseroan lain yang telah ada yang mengakibatkan aktiva dan pasiva dari perseroan yang menggabungkan diri tersebut beralih karena hukum kepada perseroan yang menerima penggabungan dan selanjutnyastatus badan hukum perseroan yang menggabungkan diri tersebut berakhir karena hukum. dalam Pasal 1 angka 1 Peraturan Pemerintah Nomor 27 Tahun 1998 Tentang Penggabungan, Peleburan dan Pengambilalihan Perseroan Terbatas menyatakan bahwa " Penggabungan dapat

11 Joni Emirzon, Hukum Bisnis Indonesia, Prenhalindo, Jakarta, 200 Hal 113 diartikan adalah suatu perbuatan hukum yang dilakukan oleh satu perseroan atau lebih untuk menggabungkan diri dengan perseroan lain yang telah ada dan selanjutnya perseroan yang menggabungkan diri menjadi bubar". Selain di dalam Undang-undang tentang Perseroan Terbatas, fenomena hukum Merger atau penggabungan perusahaan atau badan hukum diatur juga di dalam Pasal 1 angka 12 Peraturan Menteri Koperasi dan Usaha Kecil dan Menengah RI Nomor 10/Per/M.KUKM/IX/2015 Tentang Kelembagaan Koperasi yang menyatakan bahwa " Penggabungan" adalah bergabungnya satu koperasi atau lebih dengan koperasi lain". Ini berarti bahwa di dalam lembaga keuangan koperasi sangat dimungkinkan adanya Merger atau penggabungan koperasi.

Penggabungan koperasi merupakan perbuatan hukum yang dilakukan oleh satu koperasi atau lebih untuk menggabungkan diri dengan koperasi lainnya yang telah ada selanjutnya koperasi yang menggabungkan diri tersebut menjadi bubar secara hukum. mengenai penggabungan atau merger ini tentu saja harus diatur terlebih dahulu di dalam masing-masing AD/ART Koperasi sehingga memungkinkan perbuatan hukum tersebut untuk dilaksanakan. Merger atau penggabungan koperasi ini merupakan strategi bisnis yang sangat elegan dalam rangka memperkuat struktur kelembagaan koperasi, selain itu dengan adanya Merger ini maka koperasi tersebut menjadi besar dan mampu bersaing melalui ekspansi atau perluasan usaha yang meliputi penggangaran modal untuk menjamin kesejahteraan anggota sebagaimana yang diamanatkan dalam Undang-undang No 25 Tahun 1995 Tentang Perkoperasian. Hadirnya Peraturan Menteri Koperasi dan UKM ini menunjukkan keseriusan pemerintah dalam rangka memperkuat kelembagaan koperasi. Hal ini

12 http:// artonang.blogspot.co.id/2016/02/pengertianunsur-unsur-ciri-ciri.html diunduh pada Senin 19 Maret 2018 Pukul 14.00 Wita 
menunjukkan penerapan Teori Utilitas (Utilitas Theory) yang dianut oleh Jeremy Bentham yang pada intinya menyatakan bahwa hukum ingin menjamin kebahagiaan terbesar bagi manusia atau masyarakat. Hal ini senada dengan yang disampaikan oleh Erman Rajagukguk tentang peranan hukum dalam pembangunan ekonomi bahwa fungsi hukum meliputi fungsi stability yaitu fungsi hukum untuk menyeimbangkan dan mengakomodasi kepentingan-kepentingan yang saling bersaing, fungsu hukum untuk dapat meramalkan (Predictibility) akibat dari suatu langkah-langkah yang diambil khususnya penting bagi negeri yang sebagian besar rakyatnya untuk pertama kali memasuki hubungan-hubungan ekonomi yang melampui lingkungan sosial yang tradisional, serta fungsi hukum sebagai aspek keadilan (fairness) seperti perlakukan yang sama dan standar pola tingkah laku pemerintah adalah perlu untuk menjaga mekanisme pasar dan mencegah birokrasi yang berlebihan. ${ }^{13}$

Koperasi sebagai salah satu badan usaha yang berbadan hukum sangat dimungkinkan untuk melakukan penggabungan atau Merger dengan koperasi yang lain sepanjang dilakukan untuk alasan pengembangan usaha serta mempertahankan eksistensi koperasi itu sendiri agar lebih berkembang pesat. Adapun alasan dilakukannya Merger atau penggabungan usaha pada lembaga keuangan koperasi secara rinci yaitu :

1. Dikaitkan dengan tujuan pendirian koperasi yaitu untuk kesejahteraan anggota, dengan dilakukannya Merger maka kesejahteraan anggota semakin meningkat sebab dari segi kelembagaan koperasi yang melakukan Merger dengan koperasi lain akan

\footnotetext{
${ }^{13}$ Erman Rajagukguk, Hukum Ekonomi Indonesia Mmperkuat Persatuan Nasional, Mendorong Pertumbuhan Ekonomi dan Memperluas kesejahteraan sosial, Makalah disampaikan pada Seminar dan Lokakarya Pembangunan Hukum
}

semakin kuat serta mampu bersaing di era globalisasi seperti saat ini.

2. Alasan yang kedua yaitu Merger atau penggabungan usaha akan mampu menghadapi para pesaing bisnis terutama sesama lembaga keuangan sebab koperasi merupakan soko guru perekonomian nasional yang eksistensinya terjaga dengan baik di masyarakat.

3. Alasan yang ketiga yaitu berkaitan dengan dengan usaha untuk meningkatkan pertumbuhan, koperasi koperasi yang bergabung menjadi satu diharapkan kinerjanya akan semakin membaik terutama untuk perluasan usaha yang akan berimplikasi terhadap penambahan capital koperasi.

4. Alasan yang keempat yaitu meningkatkan dana dan menambah keterampilan manajemen keuangan koperasi.

Adapun prosedur secara umum koperasi melakukan Merger atau penggabungan tidak diatur di dalam Peraturan Menteri Koperasi dan UKM tetapi prosedur Meger atau penggabungan ini sama dengan Merger pada perusahaan adapun secara garis besarnya adalah sebagai berikut :

1. Tahap pertama melakukan penjajakan bagi kedua lembaga keuangan koperasi tentang kemungkinan melakukan Merger.

2. Dilanjutkan dengan melakukan persiapan oleh kedua koperasi yang akan melakukan Merger atau penggabungan usaha.

3. Pihak masing-masing koperasi akan menunjuk pihak-pihak yang akan terlibat dalam proses pelaksanaan Merger seperti Notaris, Konsultan

Nasional ke VIII yang diselenggarakan oleh Badan Pembinaan Hukum Nasional, Departemen Kehakiman dan Hak Asasi Manusia , Denpasar 14 -18 Juli 2003 
Hukum/Advokat, akuntan internal, pengawas koperasi.

4. Masing-masing koperasi sebelum mengadakan Merger perlu mengadakan Rapat Anggota yang dihadiri oleh semua anggota untuk mendapatkan pengesahan dan dukungan bahwa akan dilakukan Merger atau penggabungan usaha.

5. Akuntan internal akan mulai melakukan pekerjaannya untuk meneliti pembukuan dan neraca koperasi serta aset-aset perusahaan.

6. Konsultan Hukum masing-masing koperasi melakukan legal audit jika diperlukan.

7. Pihak masing-masing koperasi akan melakukan langkah-langkah strategis kemudian dilanjutkan dengan Konsultan Hukum/advokat membuat draf kontrak merger serta membuat rancangan perubahan anggaran dasar koperasi dengan melibatkan pihak Notaris yang ditunjuk dan perubahan tersebut harus dilaporkan kepada Menteri Koperasi dan UKM.

Mengenai perubahan atas anggaran dasar koperasi yang melakukan Merger atau Penggabungan Usaha telah diatur di dalam Pasal 14 Peraturan Menteri Koperasi dan Usaha Kecil dan Menengah RI Nomor 10/Per/M.KUKM/IX/2015 Tentang Kelembagaan Koperasi yang pada intinya menyatakan :

(1) Perubahan anggaran dasar koperasi dilakukan berdasarkan keputusan rapat anggota sesuai dengan ketentuan yang diatur dalam anggaran dasar koperasi, dilengkapi dengan:

a. Berita acara rapat anggota perubahan anggaran dasar yang dibuat dan ditandatangani oleh Notaris; dan

b. Notulen rapat anggota perubahan anggaran dasar koperasi yang ditandatangani oleh pimpinan rapat, sekretaris, salah seorang peserta rapat dan Notaris, dengan melampirkan daftar hadir anggota yang terdaftar dalam buku daftar anggota.

(2) Perubahan anggaran dasar koperasi tidak dapat dilakukan apabila koperasi sedang dinyatakan pailit.

Selanjutnya Pasal 15 Peraturan Menteri Koperasi dan Usaha Kecil dan Menengah RI Nomor 10/Per/M.KUKM/IX/2015 Tentang Kelembagaan Koperasi mengatur materi perubahan anggaran dasar koperasi dapat menyangkut beberapa hal sesuai dengan kepentingan dan kebutuhan anggota. Perubahan anggaran dasar koperasi yang menyangkut perubahan bidang usaha, penggabungan,pembagian koperasi wajib mendapat pengesahan dari Pejabat yang berwenang. Perubahan anggaran dasar koperasi yang tidak menyangkut perubahan bidang usaha, penggabungan, pembagian koperasi cukup dilaporkan secara tertulis kepada Pejabat yang berwenang Permohonan pengesahan perubahan anggaran dasar sebagaimana dimaksud pada ayat (2) diajukan secara tertulis oleh Pengurus melalui Notaris. Dalam hal Permohonan pengesahan perubahan anggaran dasar koperasi yang menyangkut perubahan bidang usaha sebagaimana dimaksud dalam Pasal 15 ayat (1) disampaikan oleh Notaris dengan melampirkan:

a. 2 (dua) rangkap Anggaran Dasar Koperasi yang telah diubah, bermaterai cukup;

b. Berita Acara Rapat, atau salinan pernyataan keputusan rapat bermaterai yang ditandatangani oleh pimpinan rapat dan diketahui Notaris;

c. notulen rapat perubahan anggaran dasar;

d. akta perubahan anggaran dasar yang dibuatsecara otentik oleh Notaris;

e. foto copy akta pendirian dan anggaran dasar yang lama yang telah dilegalisir oleh Notaris; 
f. daftar hadir rapat anggota perubahan anggaran dasar koperasi; dan

g. Nomor Pokok Wajib Pajak (NPWP) termasuk kelompok lapangan usaha (KLU).

1. Pada ayat (2) Perubahan bidang usaha koperasi sebagaimana dimaksud pada ayat (1) termasuk perubahan pola pelayanan dari konvensional menjadi pola pelayanan berdasarkan prinsipprinsip ekonomi syari'ah. Koperasi hanya dapat menerapkan 1 (satu) jenis pola pelayanan yaitu konvensional atau pola pelayanan berdasarkan prinsipprinsip ekonomi syari'ah.

Dalam hal terjadinya penggabungan atau Merger koperasi maka perubahan atas anggaran dasarnya secara teknis di atur di dalam Pasal 17 Peraturan Menteri Koperasi dan Usaha Kecil dan Menengah RI Nomor 10/Per/M.KUKM/IX/2015 Tentang

Kelembagaan Koperasi yang meliputi :

1) Permohonan pengesahan perubahan anggaran dasar koperasi yang menerima penggabungan sebagaimana dimaksud pada Pasal 15 ayat (2) disampaikan oleh Notaris dengan melampirkan:

a. 2 (dua) rangkap salinan anggaran dasar koperasi yang telah diubah, bermaterai cukup;

b. data akta pendirian dan perubahan anggaran dasar koperasi hasil penggabungan;

c. berita acara rapat perubahan anggaran dasar koperasi yang menerima penggabungan;

d. berita acara atau pernyataan keputusan rapat anggota dari

14 Wahyu Suwena Putri dan Cokorda Istri Anom Pemayun,Akibat Hukum Penggabungan Perusahaan b(Merger) Pada Perusahaan Perseroan Terbatas, OJS Unud 
yang utama. Selain itu penggabuangan koperasi tersebut harus mendapatkan izin dari Menteri Koperasi dan UKM RI. Adapun akibat atau konsekwensi hukum merger pada lembaga keuangan koperasi yaitu eksistensi koperasi yang menggabungkan diri akan berakhir demi hukum sedangkan koperasi yang mengambil alih tetap memakai nama dan identitasnya.

Akuisisi juga merupakan salah satu fenomena hukum dalam perusahaan yang juga berperan postif bagi perusahaan untuk meningkatkan pertumbuhan ekonomi daripada harus membangun usaha atau bisnis sendiri. Akuisisi merupakan mengambil alih kepentingan pengontrol terhadap suatu perusahaan yang dialkukan biasanya dengan dengan mengambil alih mayoritas saham atau mengambil alih sebagian besar aset-aset perusahaan. ${ }^{15}$ Akuisisi berbeda dengan Merger dimana salah satu perusahaan menjadi lenyap, sedangkan Akuisisi eksistensi perusahaan yang diakuisisi masih tetap ada. Tetapi dalam lembaga keuangan koperasi fenomena ini tidak pernah terjadi, yang biasa terjadi hanyalah penggabuangan usaha atau peneburan usaha koperasi sebagaimana yang diatur di dalam Peraturan Menteri Koperasi dan Usaha Kecil dan Menengah RI Nomor 10/Per/M.KUKM/IX/2015 Tentang Kelembagaan Koperasi. Padahal jika dicermati secara seksama Akuisisi lebih simple sebab koperasi tidak perlu melebur menjadi satu cukup koperasi yang telah bagus struktur keuangannya dan telah mendapatkan reputasi baik dapat mengambil alih aset-aset koperasi yang memiliki struktur keuangan yang kurang baik. Mengambil alih aset bukan berarti dijual semua kepada koperasi lain hanya dikelola saja berdasarkan perjanjian, hal tersebut dimungkinkan dalam bisnis sebagai salah satu trobosan atau strategi

15 Munir Fuady, Pengantar Hukum Bisnis Menata Bisnis Modern di Era Global, PT. Citra Aditya Bakti, Bandung $2008 \mathrm{Hal}$ 92 dalam meningkatkan usaha khususnya yang berkaitan dengan penyediaan managerial skill untuk mengelola aset-aset koperasi agar berkembang baik.

Mengenai prosedur dilakukannya Akuisisi ini sama seperti Merger sebagaimana yang telah penulis uraikan di atas. Ke depan Akuisisi dalam lembaga keuangan koperasi memang harus dimunculkan demi meningkatkan usaha koperasi sehingga kesejahteraan anggota akan terjamin. Tentu saja hal ini harus mendapatkan dukungan pemerintah dalam rangka menciptakan produk hukum yang tepat untuk mengaturnya. Akusisi yang dilakukan oleh pihak koperasi hendaknya harus memperhatikan kepentingan masingmasing pihak dalam proses Akuisisi dan tidak melawan hukum artinya tidak mengarah pada Akuisisi dengan cara bermusuhan (Take Over).

\section{PENUTUP}

Merger atau pengabungan usaha dalam lembaga keuangan koperasi telah diatur secara normatif di dalam Peraturan Menteri Koperasi dan Usaha Kecil dan Menengah RI Nomor 10/Per/M.KUKM/IX/2015 Tentang Kelembagaan Koperasi hal ini dilakukan untuk memperkuat sistim kelembagaan koperasi demi mencapai tujuan meningkatkan kesejahteraan anggota, selain itu Merger dilakukan tanpa merugikan pihak pihak dalam lembaga keuangan koperasi maupun yang berkaitan dengannya dan harus mendaspatkan izin Menteri Koperasi dan UKM. Sedangkan Akuisisi memang belum populer di kalangan pelaku koperasi tapi ke depan perlu ada payung hukum dari pemerintah sebab Akuisisi merupakan fenomena hukum yang dapat menjadi strategi bisnis yang baik pula untuk meningkatkan usaha di bidang perkoperasian, dan yang terpenting adalah 
jangan sampai Akusisi yang dilakukan merugikan salah satu pihak dan melanggar hukum.

\section{DAFTAR PUSTAKA}

Emirzon Joni, Hukum bInsis Indonesia, Prenhalindo, Jakarta, 2000Fuady Munir, Pengantar Hukum Bisnis Menata Bisnis Modern di Era Global, PT. Citra Aditya Bakti, Bandung 2008

Hadisapoetro Soedarsono, Pokok-Pokok Pikiran Pengembangan Koperasi Indonesia, CV. Sapta Caraka, 1986

Hirsanuddin, Muhaimin dan Ari Rahmad Hakim dan Yudhi Setiawan, Kewenangan Otoritas Jasa Keuangan Dalam Pengaturan dan Pengawasan di Sektor Perbankan, Jurnal Hukum Jatiswara Volume 31, No1 Maret 2016

H. Zainal Asikin \& Wira Pria Suhartana, Pengantar Hukum Perusahaan, Prenadamedia Group, Jakarta, 2016.

Ibrahim Johnny, Teori dan Metodelogi Penelitian Hukum Normatif, Bayumedia Publishing, Surabaya, 2005.

Kusnadi Hendar, Ekonomi Koperasi, Lembaga Penerbit Fakultas Ekonomi UI,2005.

Muhammad Firdaus \& Agus Edhi Susanto,Perkoperasian

Sejarah,Teori dan

Praktek,2004.MuktiFajar \& Yulianto Achmad, Dualisme Penelitian Hukum Normatif dan Empiris,Pustaka Pelajar, Yogyakarta, 2009.

Khristina Dewi Luh Putu, Tanggung Jawab Lembaga Keuangan Koperasi Terhadap Anggota Atas Perbuatan Melawan Hukum Yang Dilakukan
Pengurus Menurut Undang-Undang Nomor 25 Tahun 1992 Tentang Perkoperasian, Skripsi FH Unram, Tahun 2015.

Rajagukguk Erman, Hukum Ekonomi Indonesia Mmperkuat Persatuan Nasional, Mendorong Pertumbuhan Ekonomi dan Memperluas kesejahteraan sosial, Makalah disampaikan pada Seminar dan Lokakarya Pembangunan Hukum Nasional ke VIII yang diselenggarakan oleh Badan Pembinaan Hukum Nasional, Departemen Kehakiman dan Hak Asasi Manusia , Denpasar 14 -18 Juli 2003

Sudarsono \& Edilius,Koperasi Dalam Teori dan Praktek,PT. Rineka Cipta, 2005.

Wahyu Suwena Putri dan Cokorda Istri Anom Pemayun,Akibat Hukum Penggabungan Perusahaan $b$ (Merger) Pada Perusahaan Perseroan Terbatas, OJS Unud

Wisudawan I Gusti Agung, Jurnal Ilmiah Ganec Swara Vol 8 No 2 Edisi September Tahun 2014

http://artonang.blogspot.co.id/2016/02/pen gertian-unsur-unsur-ciri-ciri.html diunduh pada Senin 19 Maret 2018 Pukul 14.00 Wita 